\title{
Harvesting Dew with Radiation Cooled Condensers to Supplement Drinking Water Supply in Semi-arid Coastal Northwest India
}

\author{
Girja Sharan \\ DA Institute of Information and Communication Technology \\ Gandhinagar, 382007 India \\ girja sharan@daiict.ac.in, gsharan@iimahd.ernet.in
}

\begin{abstract}
This paper describes the development of dew harvesting systems for use in the semi-arid coastal region of northwest India. These systems were developed to ameliorate the drinking water problem in the region, especially for the people living near the coast where groundwater is of poor quality and surface sources are scarce. Although the amount of dew is much less $(20-30 \mathrm{~mm})$ than the rains $(200-300 \mathrm{~mm})$, it is a more consistent water source. Dew nights number approximately 100 while rainy days number 15-20. Dew occurs over a seven month period (October to April), while rain occurs over a four month period (June - September). Although engineered specifically to harvest dew, the designed systems also harvest rain, providing varying amounts of potable water throughout the year. A four-year R\&D program led to development of three types of systems - condenser-on-roof (CoR), condenser-on-ground (CoG) and Roof-as-Condenser (RaC). The CoR and CoGs systems employ condensers made of plastic film insulated on the underside. CoRs are constructed over the roof of buildings while CoGs are constructed on open ground. The RaCs use the metal roof of buildings as the condenser itself. The CoR and CoGs gave higher output but required higher investment. The RaCs gave lower output but required only a small investment in collection and storage. Examples of working installations are presented. The benefits to the region, the learning accrued, and the partnerships created in the course of work are briefly discussed.
\end{abstract}

Keywords: dew condenser; drinking water; semi-arid coastal areas

\section{INTRODUCTION}

Dew is atmospheric water vapor which condenses on a surface (wind shields, blades of grass) which has been cooled below the dew point temperature of the surrounding air by losing heat to the sky via radiation. Moisture from dew is an important means of survival for plants, arthropods and other organisms in water scarce semi-arid and arid environments ${ }^{18,24}$. However, dew is not considered to be an important source of water for humans because of the small quantities produced and its infrequent occurrence. This is true in general but there are areas where dew occurs frequently and in appreciable quantities which could be of significance to humans.

The potable water shortage in the area is widespread and chronic. More than 150 villages near the coast have no water source and the villagers survive on water hauled daily from long distance by trucks. In such a context dew water could provide a small but critical water source for humans if efficiently harvested.

Monitoring studies in the semi-arid coastal region of northwest India, initiated in 2002, indicated that dew occurred over 103 nights during a season of seven months from October to April $^{18}$ (see Figure 1). The study developed a method to collect dew water daily which was 
condensing over $124 \mathrm{~m}^{2}$ of plastic roof on a greenhouse. A total of 1191 liters was collected over the season. This equates to approximately $10 \mathrm{~mm}$ and may be considered negligible compared to the annual rainfall $(300 \mathrm{~mm})$. However, it is not negligible when considering that, at a consumption rate of 4 liters/day, an individual requires 1200 liters over the long dry portion of the year from October to May.

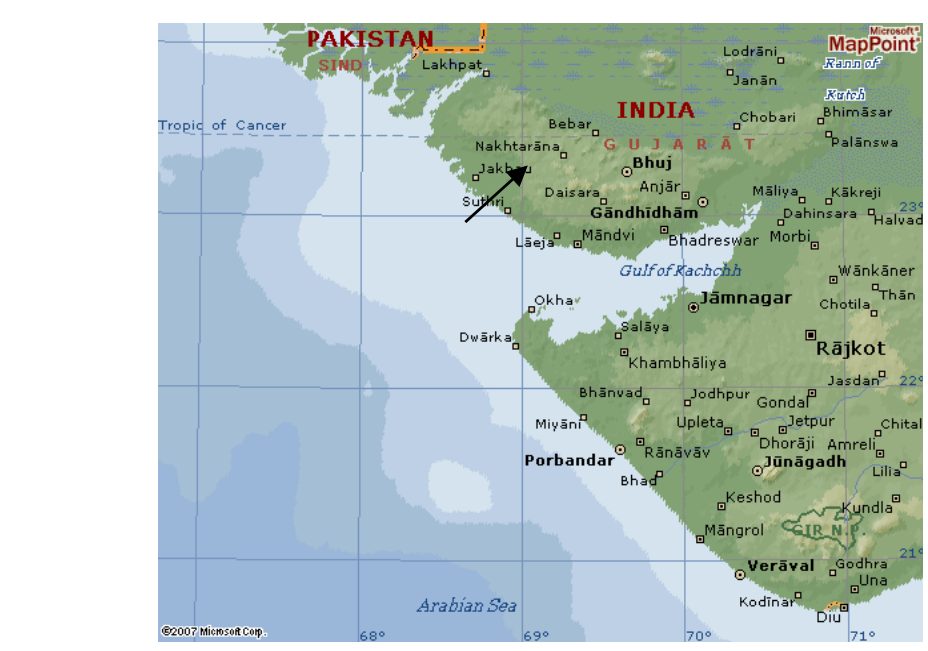

FIGURE 1

SEMI-ARID COASTAL REGION OF NORTHWEST INDIA

(Source: MapPoint)

Although dew water may have bacteriological contaminants added by air borne dust, the dew water in the study was tested and found to be potable. After filtering (where needed), dew water may be safely pasteurized (Figure 2). Another useful feature of the dew phenomena was that unlike the rains which are concentrated over 15-20 days in a season of four months, and in some years may be negligible, dew occurrence (103 nights) was more uniformly distributed over the season of seven months. Another important note is that the two seasons, rainy and dew, are complementary.

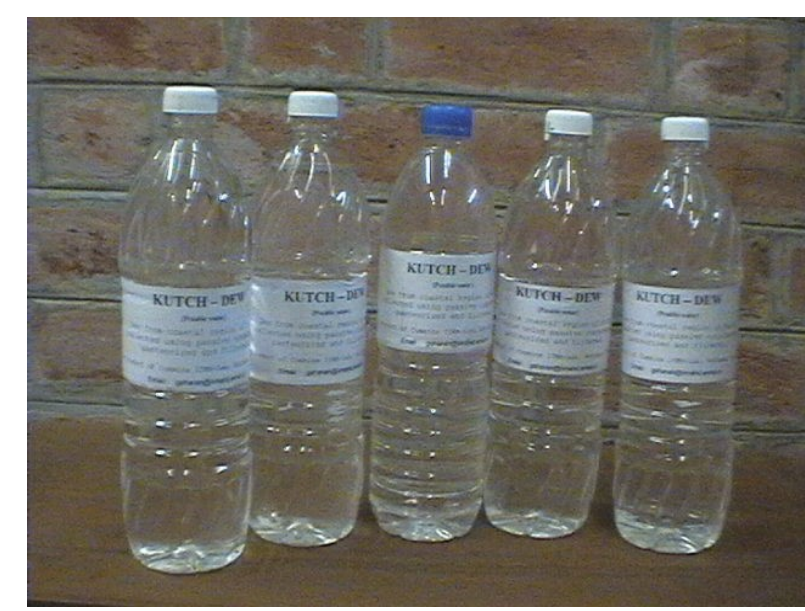

FIGURE 2

DEW WATER FILTERED WITH FINE CLOTH 
Condensation occurred frequently on the greenhouse roof because it cooled to the dew point temperature of surrounding air at night by radiating heat to sky. A search of the literature reveals a maximum potential of $0.8 \mathrm{~mm} /$ day, or $0.8 \mathrm{litre} / \mathrm{m}^{2}$, of dew water can be condensed under radiation cooling. This is based on the available cooling power $\left(25-100 \mathrm{~W} / \mathrm{m}^{2)}\right.$ in various regions with respect to the latent heat of condensation $(2.26 \mathrm{~kJ} / \mathrm{g})$. Peak collection from the greenhouse roof ( $200 \mu \mathrm{m}$ of clear polyethylene) on a night was only $0.362 \mathrm{~mm}$ or $0.362 \mathrm{liter} / \mathrm{m}^{2}$. This indicated that by employing a more efficient radiator material and with proper engineering, a larger amount of dew water could be harvested. The greenhouse roof and the classing were not specifically meant for dew harvesting.

Accordingly, a research and development project was started with the objective of developing efficient and affordable dew harvest devices for the region. The measurements cited above were carried out over months during 2002-03. The project started soon after. It took 3-4 years to gather more measurements, test prototypes, construct pilots and make working devices now available in the region. The project was led by the author from the start, through the various subsequent stages of experimentation, prototyping and field trials. Several research engineers, named in the acknowledgement, worked in the project for various length of time. Senior undergraduate students of engineering did summer internships at Kothara.

The author continues to supervise the work of promotion and the training workmen who install and repair working systems in the area. Work is also ongoing, seeking to improve the design, based on feedback from users and repair teams. Working systems are built on commission for users who may be individuals, businesses and others such as schools. The user-client pays for the installation. Only two small installations were built at small private homes at Kothara, free of cost, for demonstration and awareness raising. Similarly several sets of small condenser units were given free of cost to three high schools to help students learn about the dew phenomena. A team of workmen has been trained to install and later repair the systems. Design of new systems (sizing, configuring) accomplished by the author. This paper is an update containing information on the working installations that have since been added. An overview is provided of the following: (a) a review of the literature (b) a description of the construction of small condenser units to test materials for suitability in order to make large condensers and subsequently the construction of pilot scale units from promising materials, and finally (c) development of working systems for use by the people in the coastal region.

\section{REVIEW OF LITERATURE}

Dew has received only sporadic research attention in India with the focus of such research being mainly on assessing its contribution to moisture at the root zone for crops during dry periods. ${ }^{17}$; and to the crust of sand dunes in the Thar desert ${ }^{23}$. Efforts to develop devices to condense large amounts of dew water for human use have mostly been reported from Europe. Past efforts, especially those made in the early part of the last century, have been carefully studied by contemporary scientists ${ }^{13,14}$. Results of these studies indicate that past efforts were mostly unsuccessful because the structures erected for the purpose were massive and did not cool down to the dew-point temperature during the night. If there was any dew collected, it was much below expectation.

Peak dew collections in one night from artificial surfaces at various locations are shown in Table 1. Berkowicz et al. ${ }^{4}$ measured dew water condensation in Jerusalem using a similar condenser unit as at Kothara. They reported a collection of $33 \mathrm{~mm}$ during the 12 month 
period, over 176 dew events with a maximum in a night of $0.5 \mathrm{~mm}$. Coastal areas of the northwest, India appears to be richer in dew resource than many other locations.

\begin{tabular}{|c|c|}
\hline \multicolumn{2}{|c|}{ TABLE 1 } \\
PEAK DEW COLLECTION IN ONE NIGHT FROM ARTIFICIAL SURFACES \\
\hline Region & Collected amount ( mm ) \\
\hline Israel , Jamaica, England (south) Munich & 0.43 \\
\hline Germany ( Baltic coast) & 0.37 \\
\hline Moravia & 0.25 \\
\hline France Montpellier & 0.22 \\
\hline Moscow & 0.22 \\
\hline Romania & 0.17 \\
\hline
\end{tabular}

Interest in dew condensers has emerged again in the recent years. Current approaches differ fundamentally from the older ones. With a vastly improved understanding of the physics of condensation, efforts have been undertaken to develop light weight, more efficient, condensers made of plastic films ${ }^{12,15,16,23}$. Valuable insights on dew formation, conditions conducive to condensation, materials and substrates that give high yields have emerged from these works. It has been reported that a condensing device made of polyethylene foil pigmented with $\mathrm{TiO} 2$ and $\mathrm{BaSO}_{4}$ (abbreviated PETB here) gave peak recovery of 0.12 liter $/ \mathrm{m}^{2}$ on a night in early tests at Dodoma, Tanzania ${ }^{16}$. As will be seen presently, peak yield from similar foil was much larger in the coastal area of the northwest India.

The attributes of a good condenser and also how to erect it have been studied ${ }^{14}$. These studies indicated that "the 'ideal' condenser should be 'grass-like', i.e. a light sheet thermally isolated from the massive parts and the ground. It is important that the surfaces should be open to let them radiate the energy into space. It means that nothing that can reflect the radiation of the condenser should be placed near its surface and vice versa. The condenser itself should be placed far enough from such surfaces, e.g. the ground, to avoid the 'greenhouse' effect. The material of the sheet should be well wetted by water to reduce the nucleation barrier. Placement of the condenser should be chosen in an open area where the winds are not strong and dew is frequent (i.e. where humidity is high enough). Similar inferences can be drawn by examining equations describing the heat balance on a flat surface out in the open at night, insulated on the underside, with the top facing the sky ${ }^{19}$. For rapid cooling, the surface must have a high emissivity and a low thermal mass (be thin), a view of the sky as fully as possible, and good insulation on the back to prevent heat gain from the ground below.

Radiative cooling, critical to dew deposition, refers to the phenomena of passive cooling under a clear sky. Any surface exposed to a clear sky will emit thermal radiation into the surrounding atmosphere. It will also receive similar radiation emitted by the atmosphere. The surface will steadily cool down at night if the energy emitted is greater than that received and absorbed. If the surface cools to the dew point temperature of the surrounding air, a necessary condition for condensation of moisture from the air is created. The other conditions conducive to condensation are high levels of humidity, a calm environment, and some properties of the surface that facilitate deposition. In a tropical atmosphere, a black surface on the ground could produce up to $71 \mathrm{~W} / \mathrm{m}^{2}$ of useful cooling depending on the difference between the ambient temperature and the temperature of the colder radiating surface. The 
larger this difference, the smaller the useful cooling power. For a difference of $5{ }^{\circ} \mathrm{C}$, close to $40 \mathrm{~W} / \mathrm{m}^{2}$ cooling power could be expected to be available.

The net outgoing long wave radiation (4.5 to $100 \mu \mathrm{m})$ - which is the difference between the outgoing and the incoming - was monitored at the Indian Meteorology Department. It provided a measure of radiation-cooling power available at numerous locations. Data was collected using pyrometers at two time-points - at 05:30 and 20:30 hrs IST. Overall mean net long wave radiation over India lies between 30 to $100 \mathrm{~W} / \mathrm{m}^{2}$ (Mani) $)^{11}$. Trivandrum is a coastal location $\left(08^{0} 29^{\prime} \mathrm{N}, 76^{0} 57^{\prime} \mathrm{E}, 64 \mathrm{~m}\right.$ a.s.l) and is a humid tropical area. There, the cooling power magnitudes are from 38 to $59 \mathrm{w} / \mathrm{m}^{2}$. At Jodhpur $\left(26^{0} 18^{\prime} \mathrm{N}, 73^{0} 01^{\prime} \mathrm{E}, 224 \mathrm{~m}\right.$ a.s.l.), which is a semi-arid region of the northwest, it is above $60 \mathrm{w} / \mathrm{m}^{2}$ in all months except the rainy season - June to September. On clear nights it is higher, reaching a peak of $72 \mathrm{w} / \mathrm{m}^{2}$. Thus there is a fair amount of cooling power available in the area of our interest, the northwest. The cooling power is one of the conditions for dew condensation; availability of highly humid air is another. Both these occur frequently near the coast in northwest region.

Atmospheric characteristics of a region have to be treated as given. It is only the radiator material, the geometry, dimensions, and orientation of the condensers that are under the control of the design engineer. Emission from the sky is low, in the band of 8-13 $\mu \mathrm{m}$, which is referred to as the 'atmospheric window'. If a radiator is developed which has zero reflectance in this band a colder surface could be achieved. ${ }^{7}$ That is because in this window the atmosphere is very nearly transparent to thermal radiation. Besides emissivity, some additional properties are also to be considered if the material is to be used to build large practical dew harvest devices. Materials used need to be safe for the collection of potable water; that is, non-toxic. It needs to be durable under long exposure to weather, particularly sun and high temperatures and wind. It should be low cost so as to keep the product water prices competitive. Working systems need to be cost-effective and affordable. It is also desirable that the material be easily available or produced close to the areas of application.

\section{DESCRIPTION OF CONDENSER UNITS}

For this project, three readily available materials were initially selected to determine their condensation efficiency. These were (a) PETB film - polyethylene mixed with $5 \% \mathrm{TiO}_{2}$ and $2 \% \mathrm{BaSO}_{4}$-similar to that used by researchers cited above, (b) galvanized iron (GI) sheet, and (c) an aluminum sheet. A PETB film of the specified composition was obtained from a local plastic processor on order. The other two were purchased from the market. GI sheets are used as roofing on large warehouses and factory sheds. Aluminum sheets too are used externally but less commonly. Both of these are expensive and not expected to be used to build condensers. These were selected only to assess the potential of existing metal roofs for production of water without the use of any other artificial surface. Specifications of the three are given below.

1. Galvanized iron (GI) sheet: new emissivity 0.23 , thickness $1.5 \mathrm{~mm}$

2. Commercial Aluminum sheet: new emissivity 0. 09, thickness $1.5 \mathrm{~mm}$

3. PETB Film (Polyethylene mixed with $5 \% \mathrm{TiO}_{2}$ and $2 \% \mathrm{BaSO}_{4}$ ) UV stabilized emissivity 0.83 , thickness $0.3 \mathrm{~mm}$.

The aim of a year-long empirical investigation was to determine the amount of dew water that would be collected per unit area by each material surface during a season and gain insights into the conditions that are conducive to condensation. A test ground was prepared at the village of Kothara ( $23^{\circ} 14 \mathrm{~N}, 68^{\circ} 45 \mathrm{E}, 21 \mathrm{~m}$ a.s.l.) with the installation of a multi-channel data logger and sensors to monitor ambient conditions. Small condenser units $(1 \mathrm{x} 1 \mathrm{~m})$, 
similar to those promoted by the International Organization of Dew Utilization (OPUR), were fabricated for the determination of the condensation efficiency of the select materials. Each unit (Figure 3) consisted of three parts - panel (A), frame (C) and collection gutter and accessories (B). The panel was made of two separate sheets laminated together with adhesive. The sheet on top was made of the material to be tested. The underside was insulated with 25 $\mathrm{mm}$ thick board of styrene foam. Panels were mounted on the frame at $30^{\circ}$ from the horizontal to facilitate draining by gravity and also efficient radiation cooling. ${ }^{2}$ Collection accessories (channel and bottle) were also fastened to the frame. The higher end of the panel is $1.5 \mathrm{~m}$ from the ground.

A total of 12 units were fabricated with four of each of the three materials. Three units (one each of three materials) were installed facing north, three south, three east and three west. All twelve were installed over a test ground at Kothara away from buildings and trees. This ground is well instrumented. Dew water was collected in the plastic bottles and the volumes were noted each morning at 08:00 a.m. The condenser surfaces were not scraped, even though some moisture was easily visible at the time of making the measurement, and which evaporated shortly thereafter. In addition to determining the amount dew water condensed by the three materials, the plan also aimed at determining the effect of orientation on output.

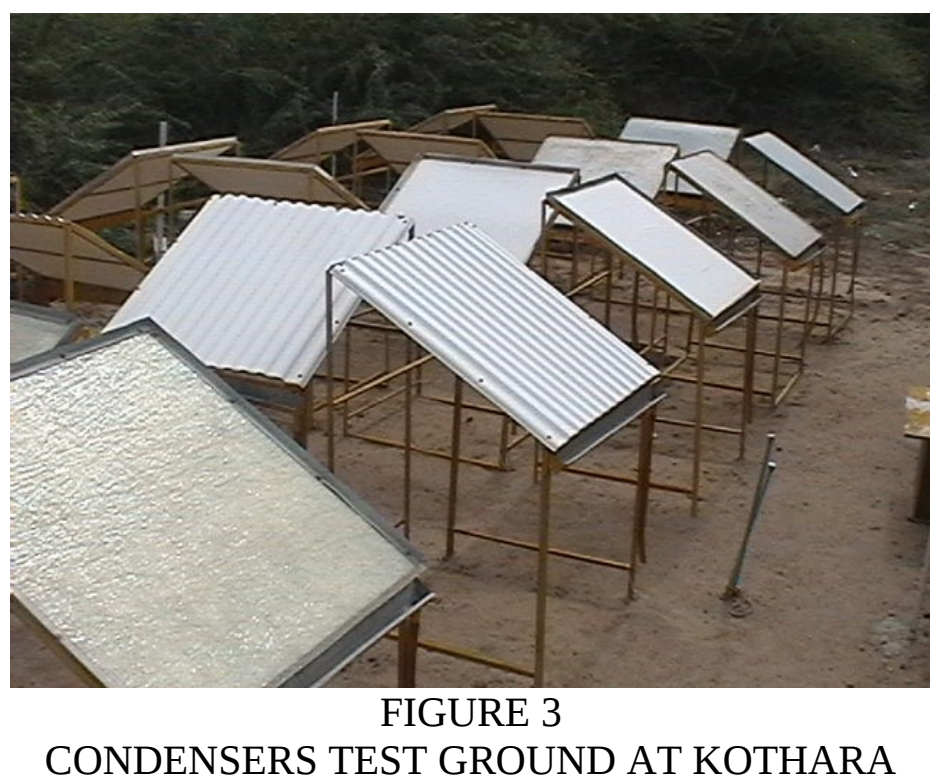

Ambient conditions at the site (air temperature, relative humidity, wind speed) were recorded continuously by a data logger (Weather Technologies India, Pune). (Table 2, Figure 4) It had an 8 channel LCD display, real time clock calendar, serial output port (RS 232C) for connection to a computer and was provided with software for data retrieval from memory module. The temperature sensors were standard Platinum RTD elements (PT 1000), model DWT 8102 mounted inside a weather shield coated with weather proof reflective white paint. The sensor resolution was $0.1^{\circ} \mathrm{C}$, with an accuracy of $\pm 0.2^{\circ} \mathrm{C}$, within the temperature range of $-40{ }^{\circ} \mathrm{C}$ to $+60{ }^{\circ} \mathrm{C}$. The relative humidity sensor was solid state capacitive (DTH 8103) type with an accuracy of $\pm 3 \%$ of full scale reading (resolution $\pm 0.1 \%$ ) and a range of 0 $99 \%$. Wind speed was measured by a three cup anemometer installed $6 \mathrm{~m}$ above ground. The anemometer assembly was mounted on a friction free shaft coupled to an 18 slot chopper. It had a starting threshold of $0.3 \mathrm{~m} / \mathrm{s}$, a range of $0-65 \mathrm{~m} / \mathrm{s}$, and an accuracy of better than \pm 0.5 $\mathrm{m} / \mathrm{s}$. These were also provided by the same company. The temperature of the condenser 
surface was measured by a similar RTD element, bonded lengthwise to the surface with thermally conductive adhesive (Product no 34313 Loctite). The element was $3 \mathrm{~mm}$ wide and $10 \mathrm{~mm}$ long. On occasions, a hand held IR thermometer (from EXTECH Instruments, France) was also used to verify surface temperature.

Condenser units were visited at intervals during the night on several occasions to observe the process of condensation. Typically the surfaces would be dry til about 22:00 hours; thereafter tiny dots of moisture would be deposited on it. Gradually these would become more numerous covering the entire surface and also would become larger. Bigger ones would touch the neighbouring droplets and coalesce. Draining of water down the surface could be seen soon after midnight and would continue till the morning hours. On the nights when large amounts of dew condensed, the relative humidity would be upwards of $85 \%$ past midnight and the condenser surface would cool below the ambient by $4{ }^{\circ} \mathrm{C}$ or more, with calm winds. The dew point temperature shown on the graph was computed using relative humidity values.

\begin{tabular}{|c|c|c|c|c}
\hline \multicolumn{5}{|c}{ TABLE 2 } \\
\hline Hour & $\begin{array}{c}\text { Amb. Temperature } \\
\left({ }^{\circ} \mathrm{C}\right)\end{array}$ & $\begin{array}{c}\text { Wind speed } \\
(\mathrm{m} / \mathrm{s})\end{array}$ & $\begin{array}{c}\text { Relative Humidity } \\
(\%)\end{array}$ & $\begin{array}{c}\text { PETB-condenser } \\
\text { Temperature } \\
\left({ }^{\circ} \mathrm{C}\right)\end{array}$ \\
\hline 1600 & 40.0 & 6.3 & 23.1 & 53.1 \\
\hline 1700 & 39.9 & 5.9 & 32.8 & 46.5 \\
\hline 1800 & 37.0 & 4.0 & 46.7 & 39.4 \\
\hline 1900 & 34.6 & 4.9 & 51.1 & 30.5 \\
\hline 2000 & 31.0 & 2.9 & 52.5 & 24.5 \\
\hline 2100 & 28.2 & 1.9 & 56.7 & 21.9 \\
\hline 2200 & 27.3 & 1.7 & 65.9 & 19.9 \\
\hline 2300 & 25.8 & 1.8 & 94.1 & 19.4 \\
\hline 0 & 23.9 & 1.4 & 96.4 & 19.6 \\
\hline 100 & 23.1 & 1.4 & 97.9 & 19.5 \\
\hline 200 & 23.6 & 2.4 & 97.7 & 20.0 \\
\hline 300 & 23.5 & 2.1 & 97.8 & 20.0 \\
\hline 400 & 22.4 & 2.1 & 98.8 & 20.5 \\
\hline 500 & 20.0 & 0.6 & 95.5 & \\
\hline 600 & 21.8 & 2.5 & 94.3 & \\
\hline Note : The dew yield on the night of $17^{\text {th }}$ & and $18^{\text {th }}$ was 290 ml on PETB unit & \\
\hline & & & & \\
\hline
\end{tabular}




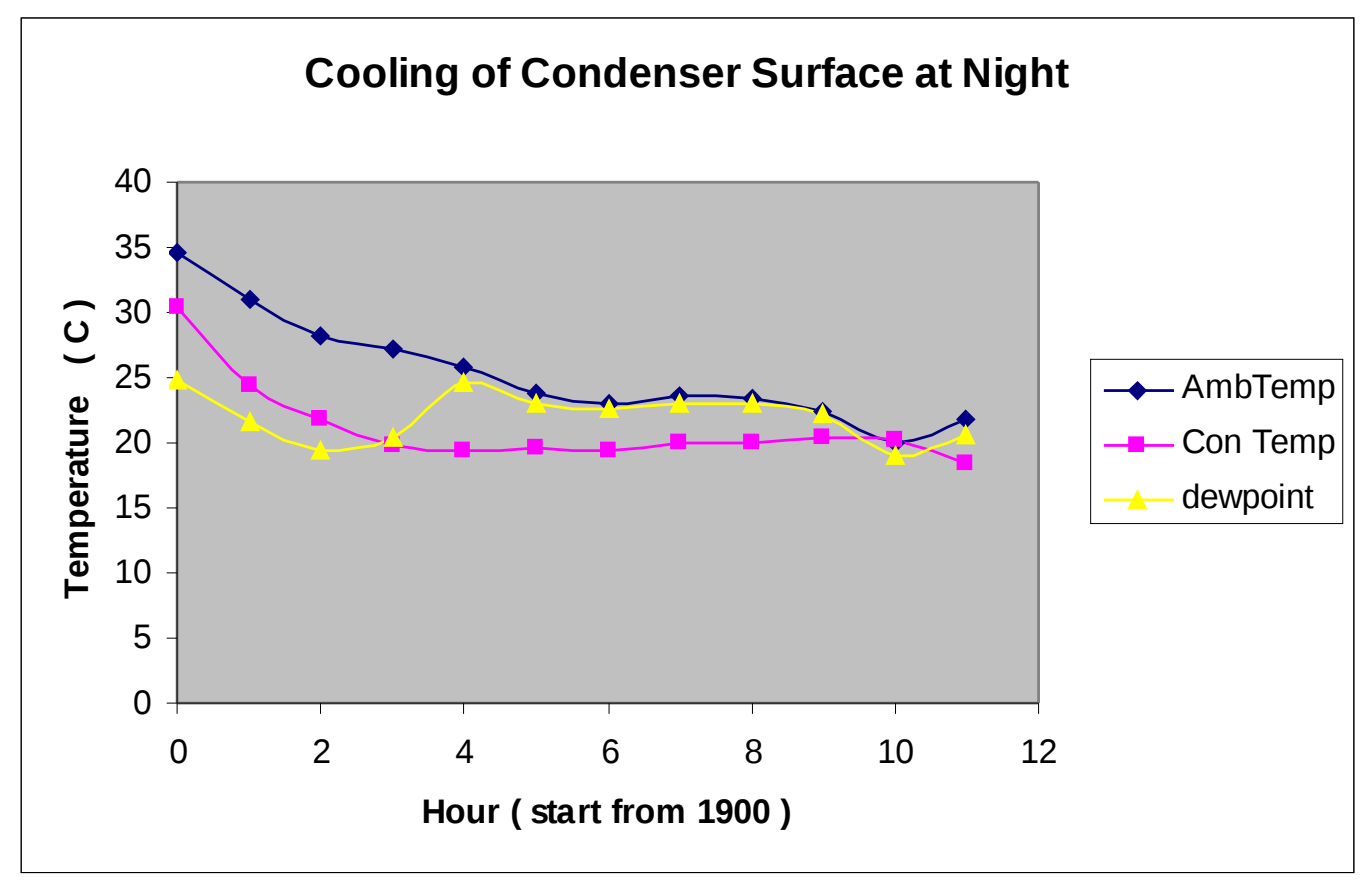

FIGURE 4

\section{COOLING OF CONDENSER SURFACE AT NIGHT}

Daily data over a two year period taken from Kothara, 2004 and 2005, was pooled and the means computed. Dew occurred in the area over a span of seven months from October to April. A small amount of condensation did occur in the last week of September before the onset and the first week of May before the close of the season. It is absent from most of May to most of September, which is the rainy season during which the sky is often covered with clouds to varying degrees and radiation cooling is hampered. There were two peaks - one centered over March - April (summer), the other over October (fall). The quantity of water collected on most (60\%) nights varied more or less uniformly between 0.05 and $0.25 \mathrm{~mm}$. The peak condensation collected on a night was $0.55 \mathrm{~mm}$.

Seasonal totals differed to a small extent with the orientation of the measurement units, higher when the units were oriented west and north. For instance, the north and the west oriented units of the PETB condensers collected nearly equal amount - $20 \mathrm{~mm}$. The east - oriented unit collected 5\% less and the south-oriented unit 15\% less. (Table 3) A plausible reason could be that the north and the west-oriented units are not exposed to illumination in the morning as early as others, permitting dew deposition for a little longer. Also for the same reason, east and south faced units may be losing more by evaporation. A more significant difference, however, was apparent when examining the material of construction. Column (6) of Table 3 shows the average collection from all four units of the three materials. The highest collection was in the PETB units $(19.4 \mathrm{~mm})$ followed by GI $(15.6 \mathrm{~mm})$ and aluminum (9 $\mathrm{mm})$. The number of nights the dew collected in the PETB and the GI units were equal, 114115. On aluminum units condensation occurred on significantly fewer (85) nights. 
TABLE 3

DEW WATER COLLECTION FROM 1x1 M CONDENSER UNITS (KOTHARA TEST GROUND)

\begin{tabular}{|c|c|c|c|c|c|}
\hline $\begin{array}{l}\text { Condenser unit } \\
\text { made of }\end{array}$ & $\begin{array}{l}\text { North - faced } \\
(\mathrm{mm})\end{array}$ & $\begin{array}{l}\text { South -faced } \\
(\mathrm{mm})\end{array}$ & $\begin{array}{l}\text { East -faced } \\
(\mathrm{mm})\end{array}$ & $\begin{array}{l}\text { West- faced } \\
(\mathrm{mm})\end{array}$ & $\begin{array}{l}\begin{array}{l}\text { All four } \\
(\mathrm{mm})\end{array} \\
\end{array}$ \\
\hline PETB & 20.3 & 17.2 & 19.7 & 20.3 & 19.4 \\
\hline GI & 18.6 & 18.7 & 11.5 & 13.7 & 15.6 \\
\hline Aluminum & 9.8 & 8.5 & 8.6 & 9.1 & 9 \\
\hline $\begin{array}{l}\text { dew nights for } \\
\text { Values are mear }\end{array}$ & $\begin{array}{l}\text { TB units } \\
\text { two years }\end{array}$ & $\begin{array}{l}114, \text { GI u } \\
\text { ad } 2005 .\end{array}$ & 115 , & units 85 & \\
\hline
\end{tabular}

\section{Pilot Scale condenser Units}

Aluminum was dropped at this stage due to poor performance results. The PETB and corrugated GI sheet were used to build pilot units. The PETB pilot was built over the ground. It was made of two $3 \times 3 \mathrm{~m}$ modules placed side by side oriented east providing a total condensing area of $18 \mathrm{~m}^{2}$ ( Figure 5). The condensing surface with the PETB film on top was insulated on the underside in the same manner as the smaller ones described above. The surface was built over a sand bed inclined $30^{\circ}$ from the horizontal, similar to the smaller units mounted on frames. The GI pilot also was of $18 \mathrm{~m}^{2,22}$ but mounted on a gable frame, one half oriented west and the other east (Figure 6). No insulation was installed underneath the GI sheets in order to mimic the existing buildings which normally are un-insulated. The pilot was $4 \mathrm{~m}$ from the ground at the ridge as the GI sheds usually are. The GI sheet was newly purchased and was $1.5 \mathrm{~mm}$ thick with a shiny surface and IR emissivity measured as 0.23 . Both halves were pitched at $30^{\circ}$. There were separate gutters and collection gear for each side. Dew water collection was measured daily over an entire season. The PETB pilot unit yielded $15 \mathrm{~mm}$ over the season (Table 4), approximately 20\% lower than that of the smaller PETB unit oriented east (19.7 mm - Table 3). The yield from GI pilots was $11 \mathrm{~mm}$ from west and $9.98 \mathrm{~mm}$ from east. These values were also lower than the corresponding small units (13.7 west, 11.5 east). In the case of the GI pilot, the main reason for the difference would appear to be lack of insulation. However the output is significant enough to encourage owners of the large GI roofed properties to use the roof to harvest dew water. Also they could be advised to improve output by installing a layer of insulation under the roof. At conclusion of the pilot tests it was decided that when new systems are built the PETB film would be employed. 


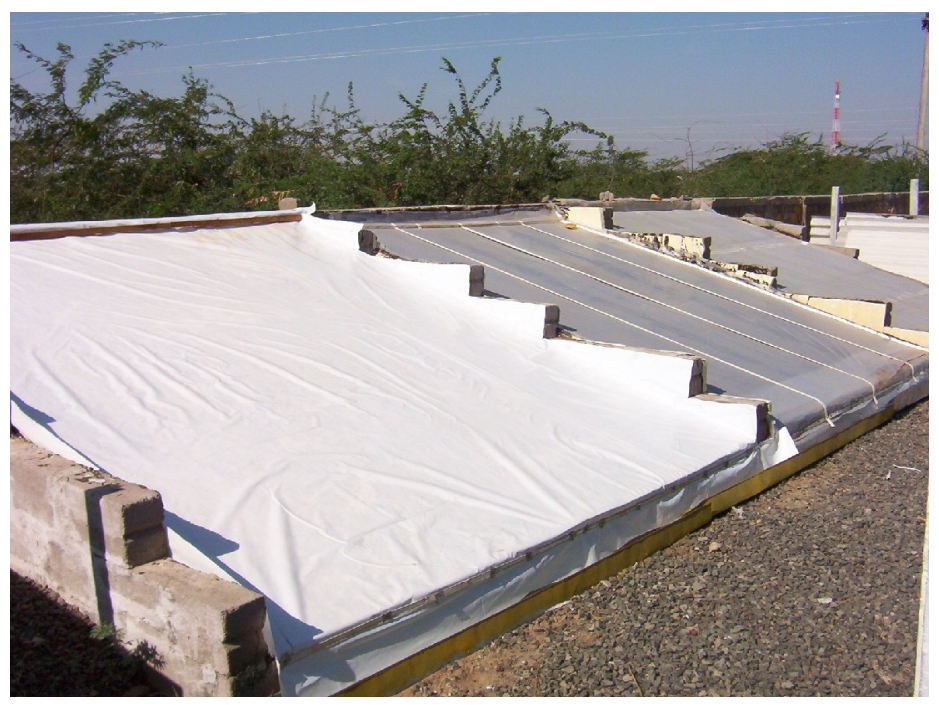

FIGURE 5

\section{PILOT PETB CONDENSER AT KOTHARA}

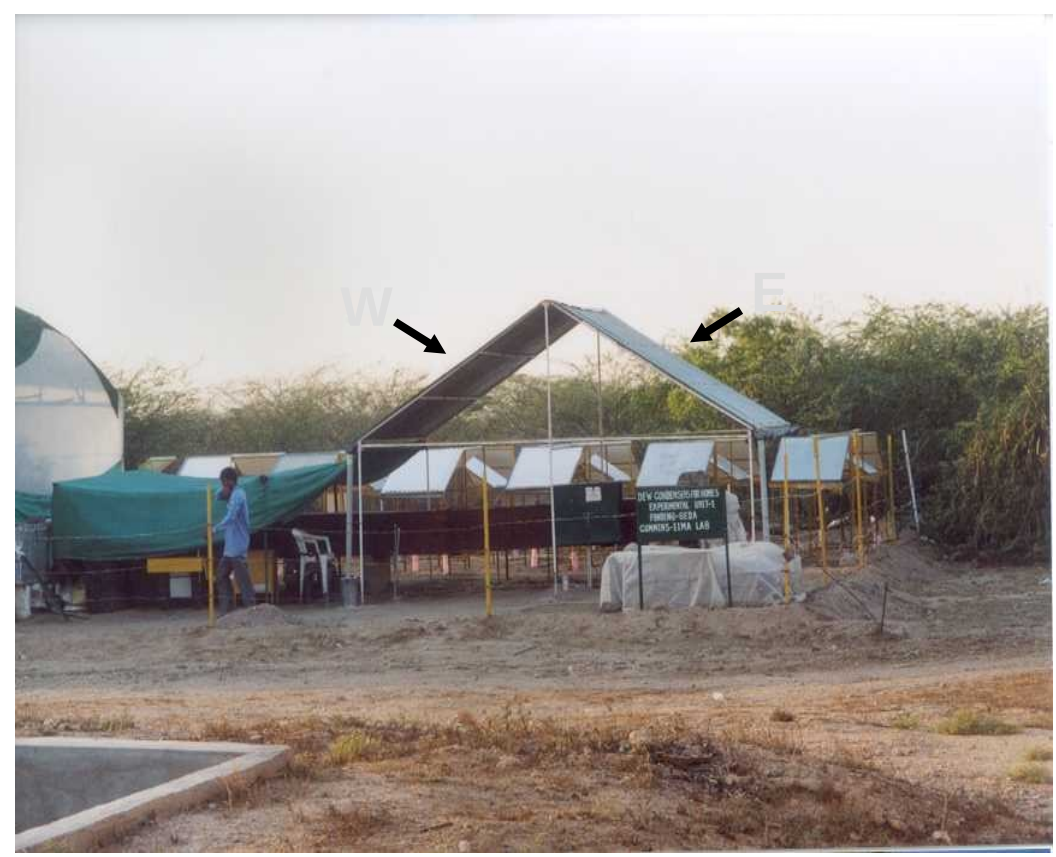

FIGURE 6

PILOT GI UNIT AT KOTHARA

TABLE 4

DEW WATER COLLECTION FROM PILOT CONDENSER UNITS

KOTHARA TEST GROUND (SEASON OCTOBER 05- MAY 06)

\begin{tabular}{|c|c|c|c|c|}
\hline $\begin{array}{l}\text { Condenser unit } \\
\text { made of }\end{array}$ & $\begin{array}{l}\text { North - faced } \\
(\mathrm{mm})\end{array}$ & $\begin{array}{l}\text { South -faced } \\
(\mathrm{mm})\end{array}$ & $\begin{array}{l}\text { East -faced } \\
(\mathrm{mm})\end{array}$ & $\begin{array}{l}\text { West- faced } \\
(\mathrm{mm})\end{array}$ \\
\hline $\begin{array}{l}\text { PETB } \\
18 \mathrm{~m} 2\end{array}$ & - & - & 15 & - \\
\hline $\begin{array}{l}\text { GI west } \\
9 \mathrm{~m} 2\end{array}$ & - & - & - & 11 \\
\hline $\begin{array}{l}\text { GI east } \\
9 \mathrm{~m} 2\end{array}$ & - & - & 9.98 & - \\
\hline
\end{tabular}




\section{EXAMPLES OF WORKING INSTALLATIONS OF DEW HARVEST SYSTEMS}

For marketing purposes, models of working systems were conceptualized. Simultaneously a campaign was carried out in the area to inform people living in the coastal villages about the dew harvest technology and to remove misgivings some held about dew water. Some residents of these villages held the view that consuming dew water is harmful for humans as well as for cattle. Open-house get-togethers were organized at the campus of the Development and Outreach Station, Kothara (the base of our research projects). The gettogethers were open to all, but formal invites were also posted to farmers, school teachers, government officers dealing with water problems and non-government-organizations operating in the area. Presentations were made to explain the working of dew harvest systems. Dew water quality, chemical and microbial test reports from accredited laboratory were explained. The amount of water that can be harvested in a season, as well as the costs of installations were discussed. Although normal water was served to visitors, dew water was also on offer and project staff made it a point to use it in these events. These events were held twice a year. Gradually the apprehensions dissolved and enquiries began to be received for installations. The installations have three components (a) the condenser surface (b) the water collection and conveyance accessories, and (c) storage. For new installations, two types were conceptualized - one with the condenser surface built over roof of buildings, termed condenser on roof (CoR), and the other built over open ground or condenser on ground (CoG). Both types would have a PETB condenser. At the same time, owners of large GI roof buildings were to be advised to use the roof itself as a condenser termed roof as condenser $(\mathrm{RaC})$.

\section{Roof-as-Condenser type system at Suthari}

The first commission to install a RaC type system was received from a temple complex at Suthari, a village $2 \mathrm{~km}$ from the coast of the Arabian Sea. Local ground water was not potable. Surface sources dried out soon after October, the last month of rainy season. The community lives on water hauled daily on tanker-trucks from a source several kilometers away. The complex had several GI roofed warehouses to store hay and offered one of the 343 $\mathrm{m}^{2}$ areas for dew harvesting (Figure 7). The roof was gabled with one half facing west and the other east, both pitched $15^{\circ}$. Being the first installation of this type it was instrumented. A temperature sensor was installed on the upper side of the roof duly shielded and bonded to surface by thermally conductive adhesive. A five channel data logger was installed to monitor roof temperature, ambient temperature, wind speed and direction and relative humidity. Table 5 and Figure 8 show the cooling of the roof on a night. At 1600 hrs in the afternoon the roof was hotter than the ambient air by nearly $11^{\circ} \mathrm{C}$. It began to cool rapidly after the sun set and became cooler than the ambient by 1900 hrs. It continued to cool reaching $4{ }^{\circ} \mathrm{C}$ below the ambient by 2200 hrs and remained cooler than the air till the morning. Relative humidity was $90 \%$ and above after midnight, with winds calm. It is in these conditions that condensation occurred. 


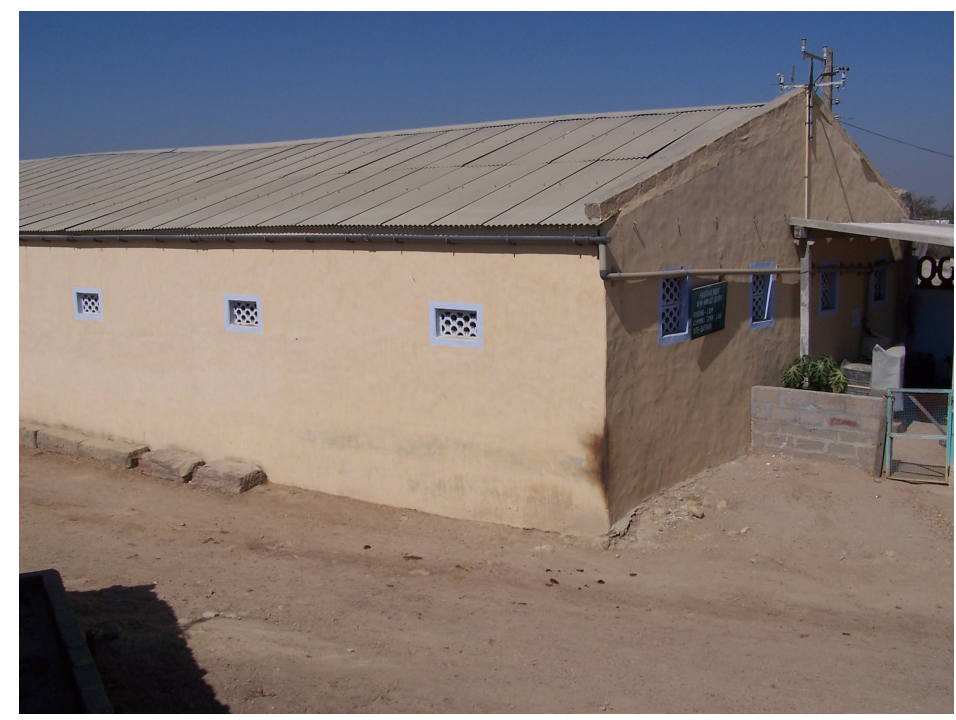

FIGURE 7

RaC TYPE SYSTEM - SUTHARI

\begin{tabular}{|c|c|c|c|c|}
\hline \multicolumn{5}{|c|}{ COOLING OF GI ROOF - RaC SUTHARI } \\
\hline Hour & $\begin{array}{c}\text { Ambient } \\
\text { Temperature ( C })\end{array}$ & $\begin{array}{c}\text { Wind speed } \\
(\mathrm{m} / \mathrm{s})\end{array}$ & $\begin{array}{c}\text { Relative humidity } \\
(\%)\end{array}$ & $\begin{array}{c}\text { Roof sheet } \\
\text { Temperature ( C) }\end{array}$ \\
\hline 1600 & 27.3 & 5.9 & 58.1 & 38.1 \\
\hline 1700 & 26.7 & 3.5 & 55.9 & 38 \\
\hline 1800 & 25.4 & 4.5 & 57.5 & 27.5 \\
\hline 1900 & 25.2 & 4.3 & 69.1 & 18.5 \\
\hline 2000 & 23.3 & 4.3 & 70.1 & 17.3 \\
\hline 2100 & 21.9 & 4.6 & 74.2 & 16.9 \\
\hline 2200 & 20 & 4.5 & 77.5 & 17.5 \\
\hline 2300 & 20.2 & 2.8 & 97.2 & 20.1 \\
\hline 0 & 22.6 & 2.1 & 92.5 & 19.5 \\
\hline 100 & 22 & 1.6 & 93.8 & 19.1 \\
\hline 200 & 21.5 & 1 & 94.7 & 16.3 \\
\hline 300 & 21.4 & 0.8 & 95.3 & 16.2 \\
\hline 400 & 21 & 0.5 & 96.1 & 15.8 \\
\hline 500 & 18.5 & 0.6 & 97.2 & \\
\hline 600 & 19.7 & 0.8 & & \\
\hline Note: 30 liters of dew water collected by & morning of March 4. & \\
\hline
\end{tabular}




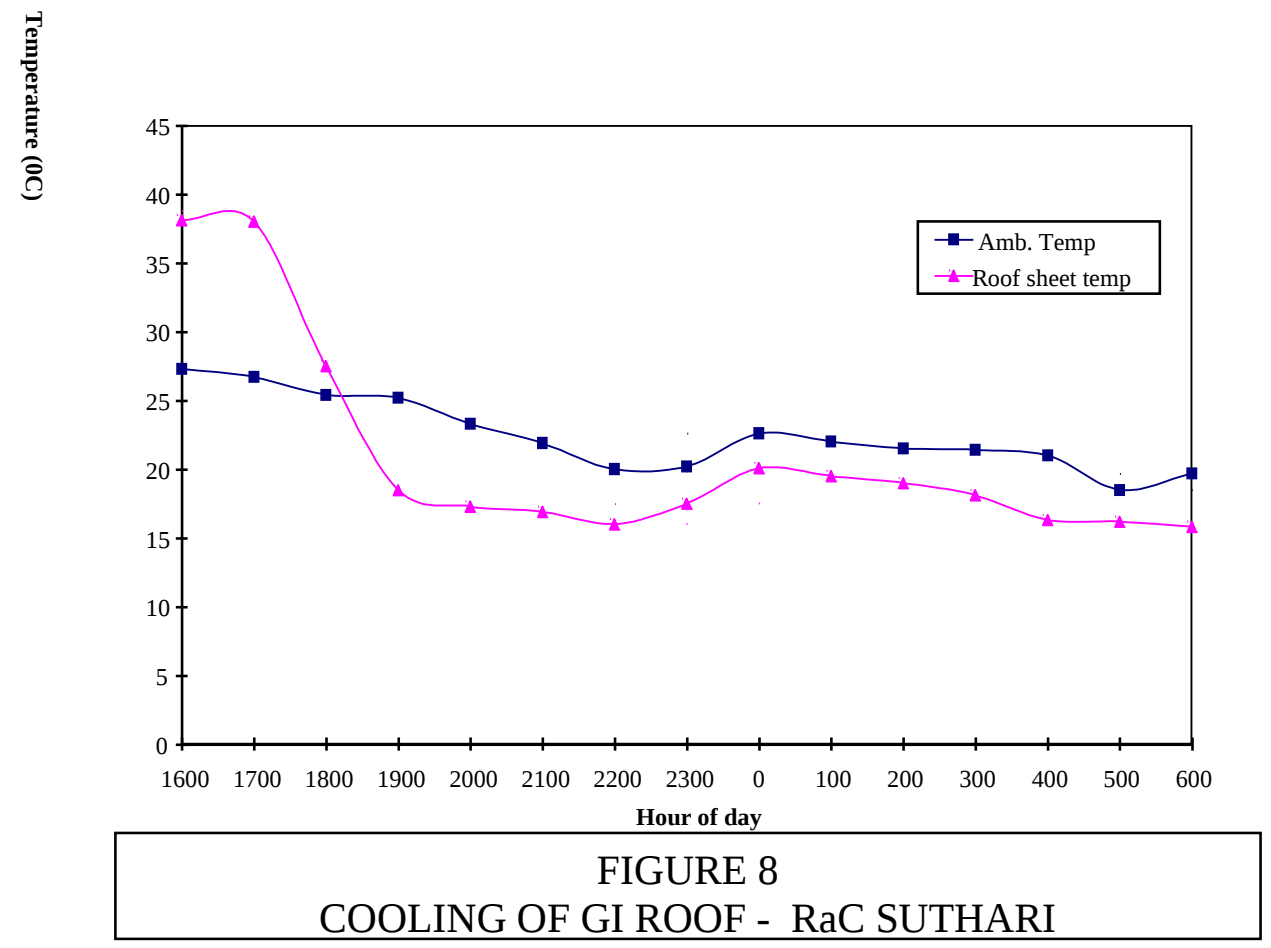

A total of 30 liters was collected by the next morning. In the year 2005, this $\mathrm{RaC}$ received 1497 liters of dew over 96 nights, in 2006, 1581 liters over 85 nights. The mean seasonal water yield was $4.5 \mathrm{~mm}$ (Table 6). This could be due to lack of insulation and due to the pitch not being steep enough ${ }^{20}$. Although the yield was low, it was obtained at only a small investment in collection gear (\$250). Water from new installations was tested in accredited laboratory at Ahmedabad at least two to tree times in the initial months after start of regular use. Findings of one of the tests are shown in Table 8. Water is generally potable. In one of the subsequent tests water showed some bacteriological contamination; that is, E Coli which may have come from air borne dust from the surrounding fields. Human excreta and cattle dropping are found in the fields. More over there was a large cattle barn right next to the warehouse. Water was rendered safe by boiling it.

The initial investment was $\$ 250$. The fittings were made of UV stabilized PVC and were expected to last over ten years. No maintenance was required, barring occasional cleaning of dust from the roofing sheet. Taking the total seasonal dew yield to be $1500 \mathrm{~L}$, and a discount rate of $10 \%$, calculations showed that the investment will be recovered in ten years if water is valued at 4 cents/L. Processed bottled water is available in the market for 20 cents/L. This is of course not generally used by people. Bulk water in $20 \mathrm{~L}$ returnable carboys is available for 3 cents/L. Considering the dew yield alone, the system is competitive with the bulk water rates. In addition to the dew water, the $343 \mathrm{~m}^{2}$ will harvest rain water. Taking $100 \mathrm{~mm}$ as the high probability rainfall in the season, a total of 34,000 L of water would be collected. Dew harvest surfaces are very efficient means of rain harvest making the systems economically more attractive.

This $\mathrm{RaC}$ was visited by a large number of people, being part of a temple complex. It provided an opportunity for visitors to taste dew water which further helped in removing their apprehensions. 


\begin{tabular}{|c|c|}
\hline \multicolumn{2}{|c|}{$\begin{array}{c}\text { TABLE } 6 \\
\text { DEW WATER COLLECTION - RaC SUTHARI }\end{array}$} \\
\hline Month & Dew water collection (liter) \\
\hline January 05 & 0 \\
\hline February 05 & 302.6 \\
\hline March 05 & 712.5 \\
\hline April $\quad 05$ & 221.0 \\
\hline May 05 & 58.0 \\
\hline June - September & 0 ( rainy season) \\
\hline October 05 & 45.0 \\
\hline November 05 & 86.0 \\
\hline December 05 & 72.0 \\
\hline Total 2005 & 1497.1 \\
\hline $\begin{array}{ll}\text { January } & 06 \\
\end{array}$ & 68.0 \\
\hline February 06 & 479 \\
\hline March & 478 \\
\hline April & 132 \\
\hline May & 84 \\
\hline June - September & 0 ( rainy season) \\
\hline October 06 & 222 \\
\hline November 06 & 45 \\
\hline December 06 & 73 \\
\hline $\begin{array}{ll}\text { Total } & 2006 \\
\end{array}$ & 1581 \\
\hline Mean of two years & $\begin{array}{c}1539 \\
(4.5 \mathrm{~mm}) \\
\end{array}$ \\
\hline Number of dew -nights were & 96 and 85 in 2005 and 2006 respectively \\
\hline
\end{tabular}

\section{Condenser-on-Roof type system at Sayara}

This CoR was commissioned by a school in Sayara, a village $15 \mathrm{~km}$ from the coast of Arabian Sea and not far from Suthari just described. Indeed the school teachers had visited there and sampled dew water over several visits. The system was installed on roofs of its three buildings. ${ }^{21}$ All roofs were pitched $15^{\circ}$, one half facing north, and other south, and were made of reinforced concrete with total area of $360 \mathrm{~m}^{2}$ (Figure 9). Styrene foam boards of 1x1 $\mathrm{m}$ size were bonded to roof surface with hot bitumen. PETB film $(0.2 \mathrm{~mm}$ thick) was fixed over the surface anchored firmly by $15 \mathrm{~mm}$ wide UV stabilized plastic ribbon. The ribbonends were screwed into the walls. Dew water flowed to the gutters and into the collection tank just below ground level. Total yield of dew water during 2005-06 was 3622 liters or 10 $\mathrm{mm}$ (Table 7). Findings from one of the tests of dew water are shown in Table 7. Note that the yield from PETB pilot unit was $15 \mathrm{~mm}$ (Table 4). But again the roof pitch at Sayara was less steep than the pilot. The condenser on the roof top made the buildings cooler inside by reducing the heat gain from the roof.

The cost of installation was approximately $\$ 1,000$. The plastic film was replaced every three years (\$240); and other fixtures are expected to last over ten tears. No maintenance is required barring occasional cleaning of dust from the condensation surface. Taking the total seasonal dew yield to be $3600 \mathrm{~L}$, and a discount rate of $10 \%$, calculations showed that the investment will be recovered in ten years if water is valued at 6 cents/L. The expected yield of rain water from $360 \mathrm{~m}^{2}$ of surface area was $36,000 \mathrm{~L}$. The school has a 20,000 L underground covered storage for the purpose. 


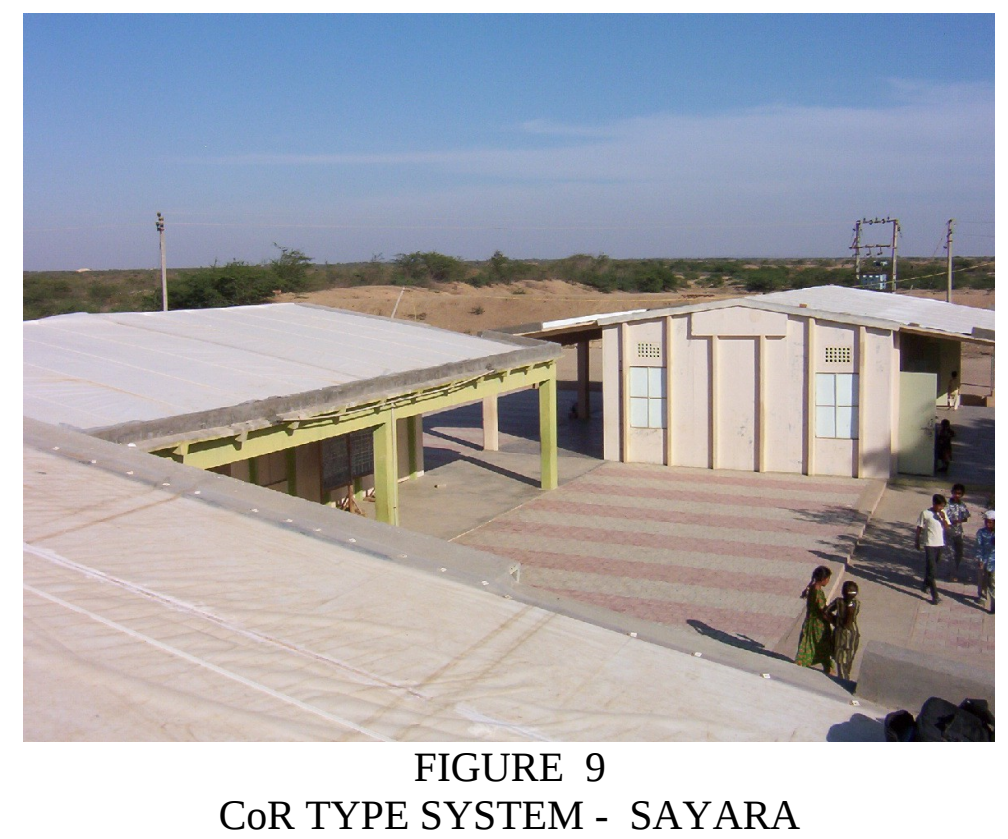

\begin{tabular}{ccc}
\hline & TABLE 7 & \\
DEW & WATER & COLLECTION - CoR SAYARA \\
\hline Month & Dew yield - all three buildings & $\begin{array}{c}\text { Dew nights } \\
\text { (no.) }\end{array}$ \\
(liters) & Data not recorded \\
October '05 & Installation incomplete & 14 \\
November '05 & 176 & 3 \\
December '05 & 151 & 8 \\
January '06 & 220 & 13 \\
February '06 & 750 & 18 \\
March '06 & 1076 & 24 \\
April '06 & 782 & 11 \\
May '06 & 465 & 92 \\
\hline Total & 3622 & \\
\hline
\end{tabular}

\section{Condenser-on-Ground type systems at Panandhro and Satapar}

A CoG type of system at Panandhro was commissioned by the Gujarat Mineral Development Corporation, a large mining company (Figure 10). Before building, dew was measured for a season using small condensers described earlier. A total of $16 \mathrm{~mm}$ was collected and there was only a small variation with orientation. The site was judged suitable for dew harvest. Also the land is of low fertility. Accordingly it was decided to build a CoG type system ${ }^{5}$. The condenser field consists of an array of ten ridge-and-trough modules built next to each other. Ridges, each $35 \mathrm{~m}$ long, were first formed by bucket excavators over gently sloping ground. Ridges are oriented along the slope of the ground. Each ridge is trapezoidal (top $50 \mathrm{~cm}$, base $200 \mathrm{~cm}$, two sides sloping $30^{\circ}$ from horizontal, height $100 \mathrm{~cm}$ ). The ridge is lined with PETB 
condenser panels of the type employed in Sayara roofs described above. Each module has an $85 \mathrm{~m}^{2}$ surface, with ten together providing $850 \mathrm{~m}^{2}$. All ten drained into a common collection pipe at the lower end. The pipe leads to a storage located in the centre on the lower end.

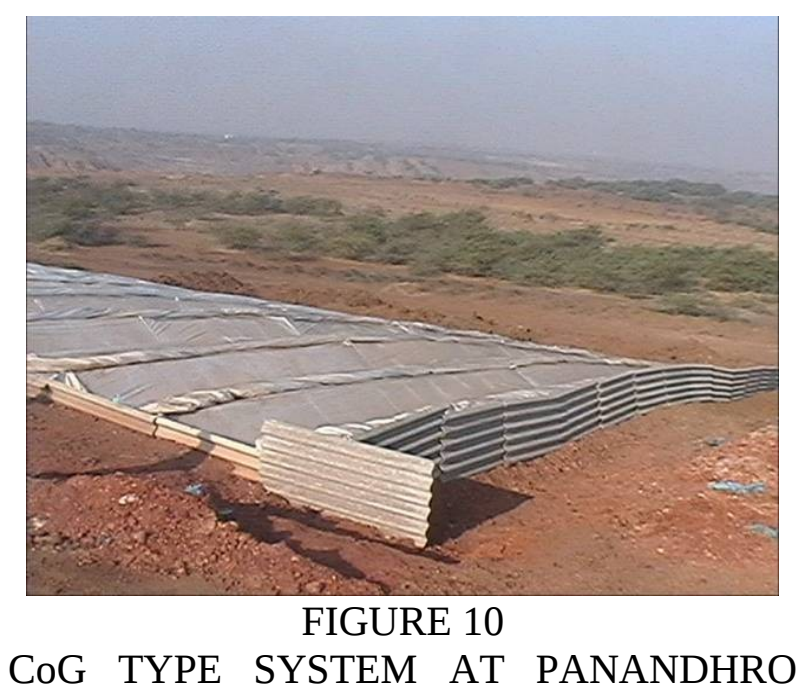

All ten ridges along with water conveyance and storage were completed by November 2006. Total dew water collection from January to November 2007 was $6545 \mathrm{~L}$ or $7.7 \mathrm{~mm}$. Measurements could not be done in the month of December. Highest yield on a single night was on February 5, 2007, when 240 liters, or $0.3 \mathrm{~mm}$, was collected. The site is in the middle of lignite mine with mining activity being carried out through out the 24 hrs. Large amounts of dust were always in the air which contaminated the dew water. Findings of one of the water test are shown in Table 8. Water is potable but acidic. Dissolved salts were also a little higher than stipulated in the ISO 10500 standards. 


\begin{tabular}{|c|c|c|c|c|c}
\hline \multicolumn{7}{c}{$\begin{array}{c}\text { Table } 8 \\
\text { Indian Standards (ISO 10500 1993) for Drinking Water } \\
\text { and Quality of Dew Water } \\
\text { at Three Installations }\end{array}$} \\
\hline Parameter & $\begin{array}{c}\text { Desired limit } \\
\text { Per IS 10500 } \\
1993\end{array}$ & $\begin{array}{c}\text { Sayara dew } \\
\text { sample }\end{array}$ & $\begin{array}{c}\text { Suthari dew } \\
\text { sample }\end{array}$ & $\begin{array}{c}\text { Panandhr } \\
\text { o dew } \\
\text { sample }\end{array}$ & $\begin{array}{c}\text { Satapar dew } \\
\text { sample }\end{array}$ \\
\hline pH & $6.5-8.5$ & 7.17 & 6.9 & 4.74 & 6.85 \\
\hline conductivity & & 520 & 930 & 1002 & 230 \\
\hline color & 5 max. & 3.0 & 2.0 & 2.0 & 3.0 \\
\hline odour & unobjectionable & Agreeable & agreeable & Agreeable & agreeable \\
\hline turbidity & 5 NTU max. & 2.0 & 1.0 & 1.0 & 2.0 \\
\hline $\begin{array}{c}\text { Total dissolved } \\
\text { solids }\end{array}$ & 500 max. & 340.0 & 610 & 660 & 155 \\
\hline Total hardness & 300 max. & 96.0 & 228 & 480 & 95.0 \\
\hline Chlorides & 250 max. & 57.0 & 161.0 & 57 & 32.0 \\
\hline Sulphates & 200 max. & 30.0 & 53.0 & 80 & 17.0 \\
\hline fluorides & 1.0 max. & 1.0 & 0.46 & 0.87 & Not detectable \\
\hline $\begin{array}{c}\text { Phenolphthalein } \\
\text { alkalinity }\end{array}$ & & Not detectable & Not detectable & $\begin{array}{c}\text { Not } \\
\text { detected }\end{array}$ & Not detectable \\
\hline Total alkalinity & 200 max. & 200.0 & 200.0 & 60 & 90.0 \\
\hline acidity & & 60.0 & 80.0 & 45 & 30 \\
\hline $\begin{array}{c}\text { MPN Index / 100 } \\
\text { ml }\end{array}$ & - & - & $<2$ & $<2$ & - \\
\hline $\begin{array}{c}\text { Coliform } \\
\text { organisms }\end{array}$ & - & - & Absent & absent & - \\
\hline
\end{tabular}

The total expenditure on COG at Panandhro was \$ 3,100 with \$ 1000 in foil, \$1000 insulation and the rest in water conveyance and storage. The foil was replaced once after 4 years. Other components (ridges, PVC pipes and fixtures) were expected to last 15 years. Maintenance was periodic - once a week sweep of surface and any other place needed, and clearing sediment filters and clean storage tank. This is done by the company. Water was not pouch-filled mechanically. But it could be done using a pouch filling machine. Typically a 2000 pouch/hour water-pouch filling machine in the region costs $\$ 2000$. In an 8 hours day, about 20,000 pouches can be filled, with electricity consumption of $4 \mathrm{kWh}$, costing here 50 cents. Such machines are reliable, relatively low maintenance and have over 10 - 15 year life expectancy. The cost of production of water in pouches then is approximately $\$ 520$ per year, neglecting the electricity consumption. The annual yield of dew water can be taken as $7000 \mathrm{~L}$ (in 2007 it was over 6500 and December data was not recorded), which gives 7.4 cents $/ \mathrm{L}$. Expected rain water output would be 85,000 L. There are long gaps between rain events and water is needed regularly for plantations. The company has therefore been advised to build a holding structure near the COG with just 20,000 L capacity. Large storage tanks made of HDPE (more than 20 year life) would cost $\$ 1,200$, raising the annual cost to $580 \$ / Y$. When rain water storage is added, and with the realistic assumption that rain water is potable, the total output from the COG during the year would rise to nearly 100,000 L. Costs per liter would then be reduced to less than one cent.

Another CoG was built in April 2007 at Satapar, a village near the coast in Jamnagar district. It consists of eleven trapezoidal ridge condensers (Figure $11 \mathrm{~A}$ ) built over a $30 \mathrm{x} 20$ $\mathrm{m}$ ground. The ridges, each $20 \mathrm{~m}$ long, are built over gently sloping ground. The cross section ridges are identical to those at Panandhro. Each module has a $50 \mathrm{~m}^{2}$ surface, all together $550 \mathrm{~m}^{2}$. All the modules drain into a common pipe at the lower and leading to a covered storage below ground. Water for use is withdrawn by a hand pump (Figure $11 \mathrm{~B}$ ). 
Findings of one of the water test are shown in Table 8. The school normally treats the stored water with chlorine tablets. The total cost of the installation was \$2500. All CoGs and CoRs also harvest rain water in rainy season.

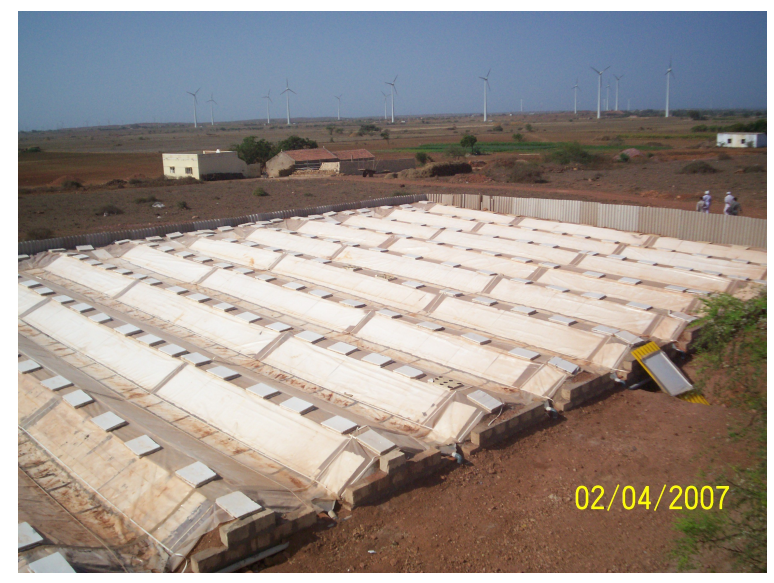

FIGURE $11 \mathrm{~A}$

CoG TYPE SYSTEM AT SATAPAR

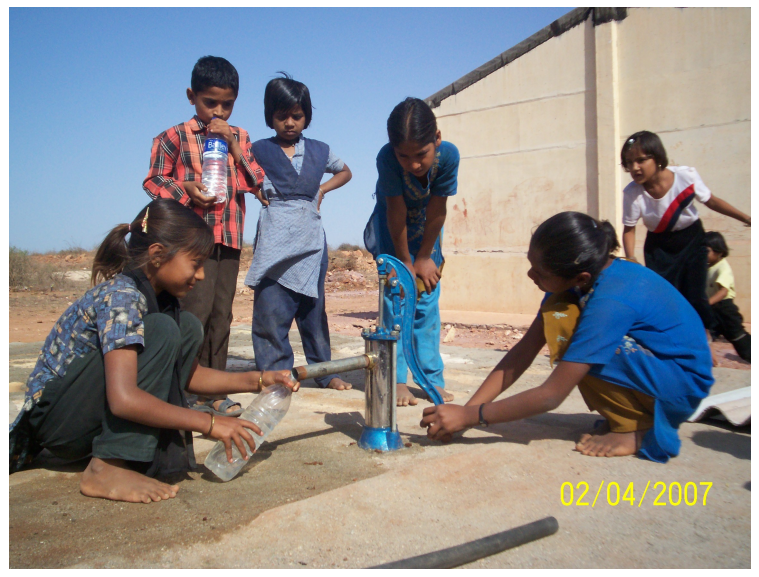

FIGURE 11 B

CHILDREN DRAWING DEW WATER - SATAPAR

\section{LEARNING}

When in 2002 the possibility of harvesting dew water for human use was visualized, there was little reliable information available on the phenomena in this region. The scientists (meteorologists, engineers) held the view that it was too little to bother. People of villages near the coast (where it frequently occurred) held the belief that consuming dew water was injurious to health. There was little prospect of getting funding support for research. To move forward it was decided to make actual measurements (amount and frequency) of dewfall by collecting dew condensation from greenhouse roof, get the water tested in accredited laboratories and publish the findings. An experimental greenhouse already existed at the Development and Outreach Station (DOS) Kothara; so no extra funds were needed to get measurements going. Publication of results was helpful in improving the attitudes of engineers and scientists. It helped in getting a small grant to make more systematic 
measurements and make measuring condensers. The first funding support came from Gujarat Energy Development Agency (GEDA). It was not directly interested in dew research, but agreed with the argument that if a significant amount of potable water could be produced locally near the coast, it would reduce the need for transport and accordingly save diesel. Test reports indicated that dew water was potable and safe. But that did not stem people's apprehensions. Eventually a more effective way was found. Periodically community gettogethers were organized at Development and Outreach Station Kothara. Filtered and boiled dew water was offered to visitors. The staff also drank that. Gradually people's attitudes also improved. The lesson learnt was that it is possible to generate support for a new idea by providing hard information and direct demonstrations.

\section{PARTNERSHIPS}

Review of literature and internet searches brought to notice the groups and individuals in other parts of the world engaged in similar pursuit - of making dew water accessible for human use. Whenever the information generated by others was useful, we communicated with them. That was how contact was made with Dr. Daniel Beysens and Iryna Milimouk of International Organization of Dew Utilization (OPUR), Paris. Seeing the commonality of interest and approach, they both traveled to our project site at Kothara. A collaboration ensued which continues. It reduced the time needed to develop practical condensers. The learning from that experience was that collaboration with people of similar pursuit is useful and that it can be based on recognition of each other's expertise. In the course of R\&D work further difficulty was encountered in getting small quantities of plastic film for trials and construction of prototypes. Although there are a large number of plastic processors in the region, they were unwilling to respond to small quantity demands. We approached the president of plastic processors association and made a presentation on the potential significance of our work and requested cooperation. That led to partnership and arrangements were made for our small orders to be fulfilled.

\section{BENEFITS TO THE REGION}

A new source of potable water, hitherto overlooked, has been made accessible to people living in the coastal areas of the north-west. Several working installations are now in place providing potable water during the dry part of the year. A team of installers has been trained to service the installations and build new ones on commission. The Habitat Division of the United Nations recognized the newly developed dew harvest technology as "GOOD PRACTICE "in 2006 and included it in their "BEST PRACTICES" data base. DOS Kothara hosts up to six engineering summer interns each year. One or two interns each year work on dew harvest systems. As a result, awareness of dew harvest technology has begun to spread to other areas of the country. Enquiries and requests for advice on dew harvest systems have been received from Brazil, Chile, Spain and Abu Dhabi.

\section{SUMMARY AND CONCLUSION}

Dew was recognized as a significant supplementary source of potable water in coastal areas of semi-arid north-west region of India. The technology was developed to condense and collect dew water for human use. It employs natural phenomena of radiation cooling to affect condensation without the use of any external energy. It is specially suited for remote rural locations on the coast where grid supply is unreliable and expensive. Three types of systems 
were developed - condenser-on-roof (CoR), condenser-on-ground (CoG) and Roof-asCondenser ( $\mathrm{RaC}$ ). The CoR and CoGs employ condensers made of plastic film insulated on the underside. The CoRs are constructed over the roof of buildings, while the CoGs were constructed on open ground. Harvest installations are affordable, easy to install and to maintain. The RaCs use metal roof of existing properties itself as condensers, requiring only a small investment in collection and storage. The CoR and CoGs give higher output, but require higher investment. The cost of dew water varied from 4-8 cents $/ \mathrm{L}$, the lowest in a $\mathrm{RaC}$ followed by CoR and CoG. These costs are much lower than the processed water sold in one litre bottles in the market ( 20 cents/L). These are closer to the cost of processed water sold in $20 \mathrm{~L}$ returnable carboys (4 cents/L). Although engineered specifically to harvest dew, the new systems harvest rain also very efficiently. When the amount of harvested rain water is accounted for, the cost of product water reduced to less than one cent a litre. The systems are a source of varying amount of water through all twelve months.

\section{ACKNOWLEDGEMENT}

Dr. James Robert Cooke of Cornell encouraged the attitude of taking up significant problems to solve; and solving them using rigorous engineering analysis. It was because of that attitude that I elected to work on dew harvest technology, hitherto overlooked in India. Funding support for this work came from Gujarat Energy Development Agency and subsequently from winner-award of India Country level Development Marketplace (2004) from the World Bank. Mr. Shashank Singh, Mr. Sanjay Kumar and Mr. M.P. Chandra worked as research engineers in the project at various stages. Mr. Owen Clus worked at Panandhro site at the time of construction and subsequently carried out studies on its performance for his thesis.

\section{REFERENCES}

1. Baier, W. (1966). Studies on Dew Formation under Semi-Arid Conditions. Agricultural Meteorology, 3, 103-112.

2. Beysens, D., I. Milimouk, V. Nikolayev, M. Muselli, J. Marcillat, (2003). Using radiation cooling to condense atmospheric vapor: a study to improve water yield, Journal of Hydrology, 276, I - II.

3. Beysens, D., I. Milimouk-Melnytchouk, M. Muselli, Condenseurs radiatifs de rosée,Techniques de l’Ingénieur, base documentaire « Génie énergétique », IN101, 042009.

4. Berkowicz, Simon M., Beysens, D., Iryna Milimouk, Bert G. Heusinkweld, Marc Muselli, Eliyahu Wakshal and Adrie F.G. Jacobs ( 2004). Urban Dew Collection Under Semi-arid Conditions : Jeruslem, Proceedings of the Third International Conference on Fog, Fog Collection and Dew, Cape Town, South Africa, October 11 - 15, 2004. Paper E 4.

5. Clus O, G. Sharan, S. Singh, M. Muselli, D. Beysens (2007) Simulating and Testing a very large dew and rain harvester in Panandhro(NW India), Proceedings of Fourth International Conference on Fog, Fog Collection and Dew, July 22-27, 2007, La Serena, Chile.

6. Choudhary, A, H.P. Das and R.K. Mukhopadhyay (1990) Distribution of dew and its importance in moisture balance for rabi crops in India, Mausam, 44,4,547-554. 
7. Granqvist C. G. and T.S. Eriksson ( 1991) Materials for Radiative Cooling to Low temperatures, In Granqvist C. G (Ed) Material Science for Solar Energy Conversion Systems, Pargamon Press , 1991.

8. Malek, E., Greg McCurdy and Bradley Giles (1999). Dew Contribution to the Annual Water Balances in Semi-arid Desert Valleys, Journal of Arid Environment, 42, 71-80.

9. Monteith, J. L. (1957). Dew, Quart. J. of the Royal Meteorological Society, 83, 22, 322341.

10. Monteith, J. L. (1963). In The Water Relations of Plants, Eds. A.J. Rutter and F.H. Whitehead, Oxford, pp 37.

11. Mani, Anna (1980) Handbook of Solar Radiation Data for India Allied Publishers, New Delhi.

12. Muselli, M., Beysens, D., Marcillat, J., Milimouk, I., Nilsson,T., Louche,A. (2002) De water collector for potable water in Ajaccio (Corsica Island France) Atmos. Res 64, 297312 .

13. Mylymuk, I., D. Beysens, A la Poursuite des Fontaines Aériennes ou Les Incroyables Aventures de Français en Ukraine, livre (Book-eBook, Sofia-Antipolis, 2005) 155 p.

14. Nikolayev, V.S., D. Beysens, A. Gioda, I. Milimouk, E. Katiouchine, J. P. Morel, (1996). Water recovery from dew, Journal of Hydrology 182, 19-35.

15. Nilsson, T., W.E. Varghas, G.A. Niklasson, C.G. Granqvist (1994). Condensation of water by radiative cooling, Renewable Energy, Vol. 5 (f), 310-317.

16. Nilsson, T. (1996). Initial experiments on dew collection in Sweden and Tanzania, Sol. Energy Mat. Sol. Cells, Vol. 40, 23-32.

17. Raman, C.R.V., S. Venkatraman and V. Krishnamurthy (1973). Dew Over India and Its Contribution to Winter-Crop Water Balance. Agricultural Meteorology, 11, 1735.

18. Sharan, G. and Hari Prakash (2003). Dew condensation on greenhouse roof at Kothara (Kutch). Research Note. Journal of Agriculture Engineering, Vol.40 (4), October-December, pp.75-76.

19. Sharan, G. ( 2007 ) Dew Condensers - From incidental discovery of possibility To a market product, In Proceedings of NCIIA $11^{\text {th }}$ Annual Meting, March 22-24, 2007, Tampa Fl (www.NCIIA.org)

20. Sharan, G., Shah, R., Millimouk-Melnythouk, I, and Beysens, D. "Roofs as Dew Collectors: I. (2007 a) Corrugated Galvanized Iron Roofs in Kothara and Suthari (NW India), Proceedings of Fourth International Conference on Fog, Fog Collection and Dew, July 22-27, 2007, La Serena, Chile.

21. Sharan, G., Singh, S., Millimouk-Melnythouk, I, Muselli, M and Beysens, D. (2007 b) "Roofs as Dew Collectors: III. Special Polyethylene Foil on a School in Sayara (NW India), Proceedings of Fourth International Conference on Fog, Fog Collection and Dew, July 22-27, 2007, La Serena, Chile.

22. Sharan, G. Beysens, D. and Milimouk, I, (2007 c) Study of Dew Water Galvanized Iron Roof in Kothara (North-West India),” Journal of Arid Environment, vol 69, Issue 2, April 2007 pp 259-269. Elsevier, Cambridge, UK.

23. Subramaniam, A.R. and Kesava Rao A.V.R. (1983). Dew fall in sand dune areas of India, International Journal of Biometeorology, Vol.27, no 3, September.

24. Zangvil, A. (1996). Six Years of Dew Observations in the Negev Desert, Israel. Journal of Arid Environment, 32, 361-371. 